\title{
GEOMETRI DAN PERMASALAHANNYA DALAM PEMBELAJARAN MAHASISWA PENDIDIKAN MATEMATIKA
}

\author{
Eva Susanti ${ }^{1}$, Haris Kurniawan ${ }^{2}$ \\ ${ }^{1,2}$ Pendidikan Matematika, Universitas Tamansiswa Palembang \\ romeo_evss@yahoo.co.id
}

\begin{abstract}
This study aims to identify geometry problems in learning in mathematics education students. This study uses a meta-analysis method with research subjects in the form of 4 documents taken from educational research journals. The results of this study are geometry problems that include problems related to logic skills, drawing skills, visual skills, verbal skills, and applied skills, deductive use such as proof problems, and perception problems become the main problem. Misconceptions about visual processes and activities, and finally problems using procedures, concepts and principles. This requires change by applying changes in learning styles. In learning, students must involve discussion, exploration, investigation, and conjecture to improve the ability to think geometry.
\end{abstract}

Key Words: Mathematics; Geometry Learning.

Abstrak: Penelitian ini bertujuan untuk mengidentifikasi permasalahan geometri dalam pembelajaran pada mahasiswa pendidikan matematika. Penelitian ini menggunakan metode meta analisis dengan subjek penelitian berupa dokumen 4 artikel yang diambil dari jurnal penelitian pendidikan. Hasil dari penelitian ini adalah permasalahan geometri meliputi permasalahan yang berkaitan dengan keterampilan logika, keterampilan menggambar, keterampilan visual, keterampilan verbal, dan keterampilan terapan, penggunaan deduktif seperti masalah buktikan, dan permasalahan persepsi menjadi permasalahan teratas. Miskonsepsi terhadap proses dan kegiatan visual, serta terakhir permasalahan penggunakan prosedur, konsep, dan prinsip. Hal ini memerlukan perubahan dengan cara menerapkan perubahan dalam gaya pembelajaran. Dalam pembelajaran sebaiknya mahasiswa melibatkan diskusi, eksplorasi, investigasi dan konjektur untuk meningkatkan kemampuan berpikir geometri.

Kata Kunci: Matematika; Pembelajaran Geometri

\section{PENDAHULUAN}

Geometri merupakan salah satu cabang dari ilmu matematika yang mempelajari tentang ukuran, letak dan bentuk suatu benda atau objek. Geometri menjadi salah satu mata kuliah yang wajib ditempuh oleh mahasiswa program studi pendidikan matematika. Konsep-konsep abstrak menjadi ciri khas dari pembelajaran geometri ini. Belajar geometri dapat mendorong mahasiswa untuk berlatih abstrak, dalam setiap mengerjakan penyelesaian masalah (Budiman, 2015).

Dalam pembelajaran geometri mahasiswa membutuhkan kemampuan berpikir matematika yang matang agar dapat memahami konsep-konsep pada geometri dan dapat menyelesaikan 
masalah-masalah nyata yang berkaitan dengan geometri. Namun pada kenyataannya dalam mempelajari geometri tidaklah mudah. Mahasiswa merasakan kesulitan dalam memahami geometri. Karena bahasan geometri memerlukan keterampilan visualisasi, intiusi, perspektif, berpikir kritis, pemecahan masalah, membuat konjektur, penalaran deduktif, argumen yang logis dan pembuktian. Semua itu memerlukan keterampilan berpikir geometri dalam mempelajarinya. Berdasarkan pengalaman mengajar, mahasiswa merasakan kesulitan dalam membayangkan sebuah ruang, menentukan jarak antara garis ke garis dalam sebuah ruang, menggambar ruang, menentukan keputusan rumus apa yang digunakan dalam sebuah permasalahan geometri dan sebagainya. Hal ini menyebabkan kurangnya minat siswa terhadap geometri.

Kekurangan dalam memahami geometri sering menyebabkan kurang semangatnya peserta didik dalam mempelajari geometri, sehingga pencapaian nilainya relatif rendah (Budiman, 2015). Namun pembelajaran geometri juga dapat meningkatkan ketertarikan anak pada matematika. Secara visualisasi, geometri memberikan daya tariknya terhadap gambar-gambar ruang. Pembelajaran geometri juga dapat meningkatkan minat anak terhadap matematika, meningkatkan ketrampilan pemecahan masalah, penalaran dan kemudahan dalam mempelajari berbagai topik matematika serta ilmu yang lain (Lipianto \& Budiarto, 2013).
Beberapa faktor yang menyebabkan kesulitan dalam mempelajari geometri telah diteliti oleh beberapa peneliti baik dari sisi bahasa dalam soal geometri, kemampuan visualisasi, dan kurang efektifnya pengajaran yang diberikan. Rendahnya keterampilan penalaran mahasiswa dipengaruhi oleh pendekatan pembelajaran geometri di kelas, mahasiswa lebih banyak mengingat daripada diarahkan pada kemampuan penalaran. Pengetahuan calon guru dalam berpikir geometri perlu diketahui dan ditingkatkan agar mampu memahami dan menjelaskan materi geometri yang diberikan kepada para siswa saat menjadi guru kelas. Karenanya geometri dan permasalahan pada mahasiswa pendidikan matematika merupakan hal yang penting bagi mahasiswa calon guru dan dosen sebagai pengajar. Oleh karena itu peneliti tertarik untuk melakukan penelitian dengan judul Geometri dan permasalahannya dalam pembelajaran mahasiswa pendidikan matematika.

\section{TINJAUAN TEORETIS}

\section{Pembelajaran Geometri}

Geometri merupakan salah satu cabang ilmu matematika yang memuat banyak konsep di dalamnya. Dari sudut pandang matematika, geometri menyediakan pendekatan-pendekatan pemecahan masalah, misalnya gambargambar diagram, sistem koordinat, vektor dan transformasi. Sedangkan dari sudut pandang psikolog, geometri merupakan penyajian abstraksi dari pengalaman visual dan spasial, 
misalnya bidang, pola, pemetaan dan pengukuran.

Dalam kehidupan sehari-hari geometri sangat berguna. Setiap orang seperti ilmuwan, arts, arsitek, insinyur, pengusaha perumahan adalah sebagian kecil contoh profesi yang menggunakan geometri secara regular. Budiarto (Abdussakir, 2009) mendefinisikan tujuan pembelajaran geometri adalah untuk mengembangkan kemampuan berpikir logis, mengembangkan intuisi keruangan, menanamkan pengetahuan untuk menunjang materi lain, dan dapat membaca serta menginpertasi argumen-argumen matematika. (Abdussakir, 2009)

$$
\text { Silver (Suwito, }
$$
menjelaskan bahwa pemberian tugas yang melibatkan analisis, refleksi dan investigasi dapat meningkatkan kedalaman berpikir siswa dalam mempelajari materi geometri.

\section{Manfaat Mempelajari Geometri}

Geometri memberikan cara untuk memberikan appresiasi terhadap dunia. Hal ini dikarenakan geometri dapat ditemukan tidak hanya pada struktur sistem tata surya, tetapi juga fenomena-fenomena alam seperti pada pembentukan geologi, Kristal dan batuan, tumbuhan dan bunga bahkan pada hewan. Geometri juga mencakup sebagian besar dari alam semesta sintesis kita seperti: seni, arsitektur, mobil, mesin, dan hampir segala sesuatu yang manusia ciptakan memiliki unsur-unsur yang berbentuk geometri.
Eksplorasi terhadap geometri dapat mengembangkan keterampilan dalam memecahkan masalah. Penalaran ruangan adalah bentuk pemecahan masalah yang terpenting, dan seperti tercantum dalam kurikulum di Indonesia, pemecahan masalah merupakan salah satu alasan utama dalam mempelajari matematika. Suatu permasalahan matematika akan mudah dipecahkan dengan menggunakan bahasa gambar geometri, dan merupakan sebagian dari penyelesaian.

Selain itu, geometri juga mempunyai koneksi dengan materi matematika lainnya. Di antaranya geometri dan pengukuran. Sebagai contoh, konsep pecahan dikoneksikan dalam geometri dengan konstruksi bahwa bagian terhadap keseluruhan. Rasio dan perbandingan terkait secara langsung dengan konsep kesebangunan dalam geometri.

Geometri telah digunakan sehari-hari oleh manusia. Seorang dokter segera tahu letak jantung karena kemampuan ruang yang bagus. Arsitek, seniman, insinyur, para pengembang, hanyalah beberapa profesi yang biasanya menggunakan geometri. Di rumah, geometri membantu di antaranya dalam pembuatan pagar, mendesain kandang hewan peliharaan, menata taman, dan mengatur ruang tamu.

Walle

(2001) juga mengungkapkan pentingnya mempelajari geometri, yaitu: geometri sangat berhubungan erat dengan kehidupan sehari-hari kita, geometri dapat mengembangkan keterampilan pemecahan masalah, geometri 
memainkan peran penting dalam mempelajari cabang matematika lainnya, geometri dapat digunakan dalam kehidupan sehari-hari dan mempelajari geometri sangat menyenangkan (Walle, 2001)

\section{METODOLOGI PENELITIAN}

Metode penelitian ini menggunakan metode meta analisis dengan subjek penelitian berupa dokumen artikel dari beberapa artikel yang terdapat di jurnal penelitian.

Metode ini memberikan gambaran secara umum mengenai konteks penelitian dengan cara kombinasi dan analisa hasil dari studi empiris. Kombinasi ini terletak dari kombinasi hasil studi satu dengan yang lainnya untuk mendapatkan kesimpulan mengenai studi lain yang berhubungan.

Subjek penelitian meta analisis ini mengambil 3 artikel tentang analisis permasalahan geometri baik dari kesalahan-kesalahan menganalisis geometri, dari segi pembelajaran di kelas, dan minat siswa.

\section{HASIL DAN PEMBAHASAN}

Hasil penelitian yang dilakukan oleh peneliti Hedi Budiman (Budiman, 2015) tentang kemampuan berpikir geometri mahasiswa yang dilakukan terhadap 65 mahasiswa calon guru menunjukkan para mahasiswa masih lemah dalam kemampuan berpikir geometri, baik dalam kemampuan visualisasi, analisis, dan abstraksi.

Pada pembelajaran mata kuliah yang berkaitan dengan geometri, diperlukan pemahaman konsep yang mendalam supaya tidak salah dalam memahami, disertai latihan-latihan pembuktian yang sangat menunjang dalam kemampuan berpikir geometri mahasiswa

Hasil penelitian yang dilakukan oleh Budiarto (Budiarto \& Artono, 2019) menunjukkan Permasahan Geometri berdasarkan keterampilan dasar geometri berturut-turut adalah permasalahan yang berkaitan dengan keterampilan logika, keterampilan menggambar, keterampilan visual, keterampilan verbal, dan keterampilan terapan. Ditinjau dari pembelajaran geometri dengan menggunakan sajian analitik maka permasalahan penggunakan deduktif seperti masalah buktikan, dan permasalahan persepsi menjadi permasalahan teratas. miskonsepsi terhadap proses dan kegiatan visual, serta terakhir permasalahan penggunakan prosedur, konsep, dan prinsip.

Dalam pembelajarannya melibatkan diskusi, eksplorasi, investigasi dan konjektur untuk meningkatkan kemampuan koneksi dan komunikasi peserta didik.

Hasil penelitian yang dilakukan oleh Ma'rufi dkk (Ma'rufi, Pasandaran, \& Yogi, 2018) Pemahaman konsep geometri subjek yang memiliki gaya kognitif field dependent hanya memenuhi 4 indikator yaitu: (a) menyatakan secara verbal konsep yang dipelajari, (b) mengklasifikasikan konsep berdasarkan dipenuhi atau tidaknya persyaratan, (c) menerapkan konsep secara algoritma, dan (d) menerapkan konsep dalam berbagai macam bentuk representasi. Indikator yang belum dapat SFD lakukan adalah 
mengaitkan berbagai konsep (internal dan eksternal matematika).

Pemahaman konsep geometri subjek yang memiliki gaya kognitif field independent dapat memenuhi ke lima indikator dari pemahaman konsep yaitu (a) menyatakan secara verbal konsep yang dipelajari, (b) mengklasifikasikan konsep berdasarkan dipenuhi atau tidaknya persyaratan, (c) menerapkan konsep secara algoritma, (d) menerapkan konsep dalam berbagai macam bentuk representasi, dan (e) mengaitkan berbagai konsep (internal dan eksternal matematika).

\section{Analisis permasalahan dalam pembelajaran}

Dari beberapa hasil penelitian mengenai permasalahan geometri di atas. Permasalahan terletak pada pemahaman konsep, kurangnya kemampuan berpikir geometri yang dimiliki mahasiswa, baik dalam kemampuan visualisasi, analisis dan abstraksi. Hal ini memerlukan perubahan dalam gaya belajar di kelas atau pun di rumah.

Mahasiswa sebaiknya terlebih dahulu mempersiapkan diri dengan banyak membaca tentang ilmu geometri, memperbanyak latihan penggunaan rumus-rumus abstrak yang diperlukan dalam permasalahan geometri. Dan dalam proses pembelajaran, mahasiswa diberikan keluasan berexplorasi mengenal bangun ruang di alam sekitar. Pembelajaran geometri akan terasa lebih bermakna apabila keadaan nyata disekitar diikutsertakan. Eksplorasi terhadap geometri dapat mengembangkan keterampilan dalam memecahkan masalah

Dalam hal pembuktian, mahasiswa perlu memiliki ilmu dasar atau dalil-dalil yang ada dalam geometri. Kurangnya minat mahasiswa dalam menghapal atau memahami konsep/dalil geometri membuat kesulitan dalam hal pembuktian. Hal ini perlu diperbaiki dengan banyak menghadapi berbagai permasalahan abstrak dalam geometri.

\section{SIMPULAN DAN SARAN}

Permasalahan geometri meliputi permasalahan yang berkaitan dengan keterampilan logika, keterampilan menggambar, keterampilan visual, keterampilan verbal, dan keterampilan terapan, penggunaan deduktif seperti masalah buktikan, dan permasalahan persepsi menjadi permasalahan teratas. miskonsepsi terhadap proses dan kegiatan visual, serta terakhir permasalahan penggunakan prosedur, konsep, dan prinsip. Hal ini memerlukan perubahan dengan cara menerapkan perubahan dalam gaya pembelajaran. Dalam pembelajarannya sebaiknya mahasiswa melibatkan diskusi, eksplorasi, investigasi dan konjektur untuk meningkatkan kemampuan berpikir geometri.

\section{DAFTAR PUSTAKA}

Abdussakir. (2009). Pembelajaran Geometri sesuai Teori Van Hiele. Jurnal Pendidikan dan Pembelajaran Dasar.

Budiarto, M. T., \& Artono, R. (2019). Geometri dan Permasalahannya. JUMADIKA Vol 1 No 1.

Budiman, H. (2015). Analisis Kemampuan Berpikir Geometri 
Mahasiswa Pedidikan

Matematika. Jurnal Prisma

Volume 4 No : 8 .

Lipianto, D., \& Budiarto, M. t. (2013).

Analisis Kesalahan Siswa Dalam

Menyelesakan Soal Yang

Berhubungan Dengan Persegi

Dan Persegipanjang

Berdasarkan Taksonomi Solo

Plus Pada Kelas Vii. Jurnal

Mathedunesa Vol 2 .

Ma'rufi, Pasandaran, R. F., \& Yogi, A. (2018). Pemahaman Konsep

Geometri Mahasiswa

Berdasarkan Gaya Kognitif

Mahasiswa. Jurnal Proximal vol 1 no 2.

Suwito, A. (2017). Analisis Berpikir Secara Geometri Dalam Meyelesaikan masalah aljabar kelas VIII. Prosidding seminar nasional Etnomtnesia.

Walle, V. d. (2001). Geometric Thinking and Geometric Concepts. In Elementary and Middle. Boston: Allyn and Bacon: Teaching Developmentally, 4th ed. 